\title{
Pelatihan Penguatan Brand serta Penggunaan Digital Marketing bagi Kelompok Batik Sariwarni Kabupaten Madiun
}

\author{
Wildanul Isnaini ${ }^{1 *}$, Dimas Setiawan ${ }^{2}$, Nur Ihda Farikhatin Nisa ${ }^{3}$ \\ ${ }^{1}$ Program Studi Teknik Indusri, Universitas PGRI Madiun \\ ${ }^{2}$ Program Studi Sistem Informasi, Universitas PGRI Madiun \\ ${ }^{3}$ Program Studi Teknik Kimia, Universitas PGRI Madiun \\ *wildanulisnaini@unipma.ac.id
}

\begin{abstract}
ABSTRAK
Kelompok Batik Sariwarni merupakan salah satu kelompok batik yang ada di Kabupaten Madiun, tepatnya berada di Desa Balerejo Kecamatan Kebonsari dan beranggotakan 9 ibu rumah tangga. Kelompok ini memproduksi 4 jenis batik yaitu tulis, cap, eco print, serta batik dengan pewarna alam. Kelompok batik sariwarni meproduksi batik untuk stok serta customize sesuai dengan keinginan pelanggan. Dengan cara custom ini pelanggan dapat memilih corak ataupun warna sesuai keinginan. Setelah dilakukan observasi dan wawancara kepada Kelompok Batik Sariwarni, didapatkan informasi tentang beberapa permasalahan yang ada yaitu pemasaran yang kurang optimal, kreativitas anggota kelompok yang masih perlu ditingkatkan, serta belum tersedianya Instalasi Pengolahan Air Limbah (IPAL). Dari permasalahan yang diungkapkan oleh mitra, dipilih permasalahan yang akan diselesaikan terlebih dahulu sesuai dengan disiplin ilmu yang dipunyai yaitu pemasaran Jika dilihat dari cara dan strategi pemasaran saat ini, masih ada beberapa hal yang dapat dibenahi seperti penambahan media pemasaran online, spesifikasi market place, hingga memperkuat branding. Telah dilakukan 2 pelatihan yaitu pelitahan Penguatan Brand dan Pemasaran serta Pelatihan Digital Marketing. Program pelatihan penguatan brand dan pemasaran serta digital marketing berjalan dengan lancar. Pelatihan Penguatan Brand dan Pemasaran dapat meningkatkan pengetahuan sebesar $20,37 \%$ dan pelatihan digital marketing dapat meningkatkan pengetahuan sebesar 10,91\%.
\end{abstract}

Kata Kunci: Batik Sariwarni, Pelatihan, Brand, Pemasaran, Digital Marketing

\section{ABSTRACT}

Batik Sariwarni is batik groups in Madiun Regency, located in Balerejo Village, Kebonsari District and consists of 9 housewives. This group produces 4 types of batik, they are written, stamped, eco print, and batik with natural dyes. Batik Sariwarni produces batik for stock and customize according to customer wishes. With this custom way customers can choose the style or color as desired. After observations and interviews with the Batik Sariwarni, information was obtained about some of the existing problems, namely suboptimal marketing, creativity of group members that still needed to be improved, and the unavailability of wastewater plants. From the problems revealed by partners, the issues chosen will be resolved first in accordance with the discipline they have, namely marketing. If viewed from the current marketing methods and strategies, there are still a number of things that can be addressed such as the addition of online marketing media, market place specifications, to strengthen branding. Two trainings have been conducted, namely Brand Strengthening and Marketing training and Digital Marketing Training. Brand strengthening and marketing and digital marketing training programs run smoothly. Brand and Marketing Strengthening Training can increase knowledge by $20.37 \%$ and digital marketing training can increase knowledge by $10.91 \%$.

Keywords: Batik Sariwarni, Training, Brand, Sales, Digital Marketing 


\section{PENDAHULUAN}

Dewasa ini, batik sudah dikembangkan di banyak daerah dengan mengusung keberagaman budaya dan cirikhas masing-masing daerah yang terlihat dari sejumlah motifnya. Tidak terkecuali di Desa Balerejo Kabupaten Madiun. Corak porang dan manco berhasil dikembangkan oleh Kelompok Batik Sariwarni sehingga menjadi identitas Desa Balerejo. Kelompok Batik Sariwarni diketuai oleh Siti Suwarni serta beranggotakan 9 ibu rumah tangga. Kelompok Batik Sariwarni mampu memasarkan produknya tidak hanya di Madiun tapi juga merambah ke Jakarta dan Luar Jawa. Menurut Kepala Desa Balerejo, Puguh Tri Winarso, Batik Sariwarni sangat berpotensi untuk di kembangkan serta berpotensi menjadi produk unggulan Desa Balerejo (Jawapos.com, 2016). Sehingga diharapkan bantuan serta dukungan dari beberapa pihak baik pemerintah, universitas, ataupun masyarakat.

Kelompok Batik Sariwarni memproduksi 4 jenis batik yaitu tulis, cap, eco print, serta batik dengan pewarna alam.

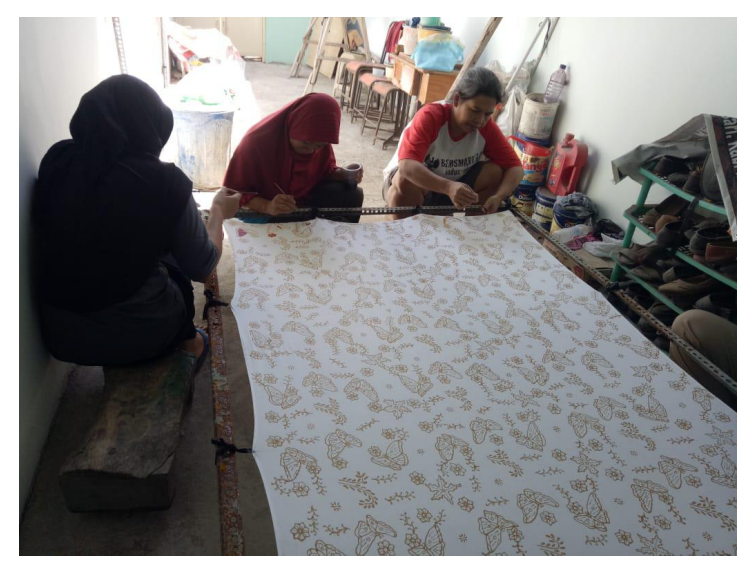

Gambar 1. Aktivitas Produksi di Batik Sariwarni

Jika dilihat dari prosesnya, masing-masing mempunyai sasaran pasar serta harga yang berberda-beda. Selaras dengan proses produksinya, batik tulis mempunyai harga yang lebih mahal jika dibandingkan dengan 3 jenis batik lainnya. Dalam sebulan, kelompok batik sariwarni dapat menjual 100 hingga 150 kain batik dengan kisaran harga $\mathrm{Rp}$
160.000. Batik tulis corak porang manto adalah yang paling laris. Kelompok batik sariwarni meproduksi batik untuk stok serta customize sesuai dengan keinginan pelanggan. Pemesanan produk custom oleh dinas atau pemerintahan lebih mendominasi penjualan jika dibandingkan dengan pembelian secara individu. Dengan cara custom ini pelanggan dapat memilih corak ataupun warna sesuai keinginan.

Setelah dilakukan observasi dan wawancara kepada Kelompok Batik Sariwarni, didapatkan informasi tentang beberapa permasalahan yang ada yaitu pemasaran yang kurang optimal, kreativitas anggota kelompok yang masih perlu ditingkatkan, serta belum tersedianya Instalasi Pengolahan Air Limbah (IPAL) yang efisien dan sesuai kebutuhan (Muljadi, 2009). Saat ini, pemasaran batik sariwarni dilakukan melalui pameran, word of mouth, facebook, serta showroom mini di sebelah rumah produksi. Pameran yang diikuti adalah pameran UMKM yang diadakan oleh dinas terkait. Melalui pameran, Batik Sariwarni dapat menjual batik lebih banyak jika dibandingkan dengan word of mouth dan facebook. Pemasaran dengan word of mouth dapat meningkatkan penjualan namun masih di area Madiun dan Kabupaten. Dengan facebook inilah penjualan batik dapat menyasar pasar yang lebih luas. Namun, kurangnya kemampuan pengoperasian media sosial menjadi kendala tersendiri.

Karena keterbatasan inilah kelompok batik sariwarni membutuhkan media dan cara pemasaran yang lebih optimal sehingga lebih dikenal serta dapat meningkatkan penjualan. Selain dari sisi pemasaran, menurut Siti Suwarni, kreativitas anggota kelompok dalam menciptakan motif atau corak perlu ditingkatkan. Motif, corak, serta paduan warna yang menarik diharapkan dapat lebih disukai pasar sehingga jumlah pejualan pun meningkat. Saat ini, corak dan paduan warna batik ditentukan oleh Ibu Suwarni, anggota kelompok batik 
hanya mengerjakan proses canting, colet, pewarnaan, dan penjemuran.

Dari permasalahan yang diungkapkan oleh mitra, dipilih permasalahan yang akan diselesaikan terlebih dahulu sesuai dengan disiplin ilmu yang dipunyai yaitu pemasaran Jika dilihat dari cara dan strategi pemasaran saat ini, masih ada beberapa hal yang dapat dibenahi seperti penambahan media pemasaran online, spesifikasi market place, hingga memperkuat branding.

\section{METODE}

Berikut adalah metode pelaksanaan dari solusi permasalahan yang di rencanakan

1) Solusi Strategis

Pemberian solusi strategis akan dilaksanakan dengan cara pemberian pelatihan. Yaitu pelatihan untuk menentukan (1) model bisnis, (2) Branding, (3) Segmenting, Targeting, Positioning (STP), dan (4) cara penentuan harga (Osterwalder, Pigneur, Smith, \& Movement, 2009). Pelatihan menggunakan 2 trainer, yaitu anggota tim atas nama Wildanul Isnaini karena sesuai dengan kepakarannya dibidang manajemen industri. Trainer kedua akan diambilkan dari praktisi yang bergelut dalam pengembangan bisnis lokal. Dalam pelatihan, anggota mitra berpartisipasi sebagai peserta sedangkan 2 anggota tim lain sebagai fasilitator kegiatan. Pelatihan dilakukan selama 4 kali pertemuan. Tiap pertemuan berisikan materi dan praktek langsung. Misalnya, pertemuan pertama akan dibahas materi tentang model bisnis, kemudian diikuti oleh praktek langsung untuk merumuskan model bisnis Kelompok Batik Sariwarni. Diharapkan, pemberian materi saat pelatihan menggunakan bahasa yang awam dan mudah dipahami oleh anggota mitra.

\section{2) Melakukan Digital Marketing}

Media pemasaran online yang dipilih adalah website, instagram, dan etsy karena sebagai media efektif dalam penyebaran iklan (Satrianti, 2018). Sebagian besar, mulai dari instalasi, pelatihan, dan pendampingan akan di lakukan oleh Dimas Setiawan. Anggota tim lain akan menjadi fasilitator serta membantu mengkondisikan anggota mitra sebagai peserta pelatihan. Langkah awal solusi ini tentu saja membuat website, instagram, dan etsy untuk batik sariwarni. Setelah itu, dilakukan pelatihan untuk mengoperasikan media tersebut. Pelatihan akan dilakukan dalam 2 kali pertemuan yaitu pertemuan pertama untuk pelatihan pengoperasian website dan pertemuan kedua untuk pelatihan pengoperasian instagram dan etsy. Diakhir pelatihan akan dilakukan praktik bersama serta pemilihan 3 admin hasil rekomendasi trainer dan persetujuan anggota kelompok. Setelah pelatihan selesai, admin terpilih akan mengoperasikan media pemasaran online secara mandiri didampingi oleh anggota tim. Selain perangkat keras dan lunak, pemasaran digital juga memerlukan foto produk yang menarik untuk diupload di media pemasaran online. Awalnya, pengambilan foto produk akan dilakukan oleh profesional. Namun, setelah itu diharapkan beberapa anggota kelompok batik sariwarni dapat melakukan secara mandiri.

Selain menggunakan instagram pribadi, digital marketing juga akan dilakukan dengan endorsement. Endorsement dilakukan dengan cara memilih selebgram dengan mempertimbangkan jumlah followers, rata-rata usia followers, serta konsep yang diusung selebgram untuk sebagian besar foto-fotonya. Pemilihan selebgram serta kesepaktan akan dilakukan oleh anggota tim. Mitra berpartisipasi dalam ketersediaan produk yang akan dikirim ke selebgram terpilih.

\section{HASIL DAN PEMBAHASAN}

Terdapat 2 pelatihan yang telah dilakukan tim pengabdian di Batik Sariwarni yaitu Pelatihan Penguatan Brand dan Pelatihan Digital Marketing.

\section{Pelatihan Penguatan Brand}

Pelatihan Penguatan Brand/Branding diisi oleh Ketua Tim Pengabdian Kepada Mayarakat sesuai dengan bidang 
keahliannya. Pelatihan ini bertujuan untuk memperkuat brand Batik Sariwarni serta menentukan arah Model Bisnis dari Batik Sariwarni. Pelatihan Branding diikuti oleh 10 anggota kelompok Batik Sariwarni yanag mayoritas merupakan ibu rumah tangga. Terdapat 3 materi utama yang disampaikan dalam pelatihan ini yaitu tentang Business Model Canvas, Segmenting Targeting and Positioning (STP), dan Penentuan Harga Pokok Produksi (HPP).

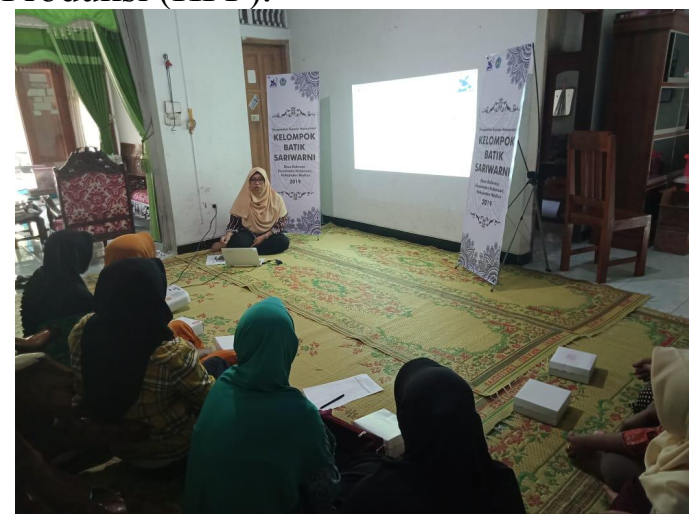

Gambar 2. Suasana saat pelatihan penguatan brand

Dalam pelatihan terdapat 5 sesi yaitu Pre Test, Penjelasan, Praktek, Post Test, dan Uji Kepuasan. Pada Pretest, peserta diminta untuk mengerjakan beberpa soal terkait materi yang akan disampaikan sebelum penjelasan materi dimulai.

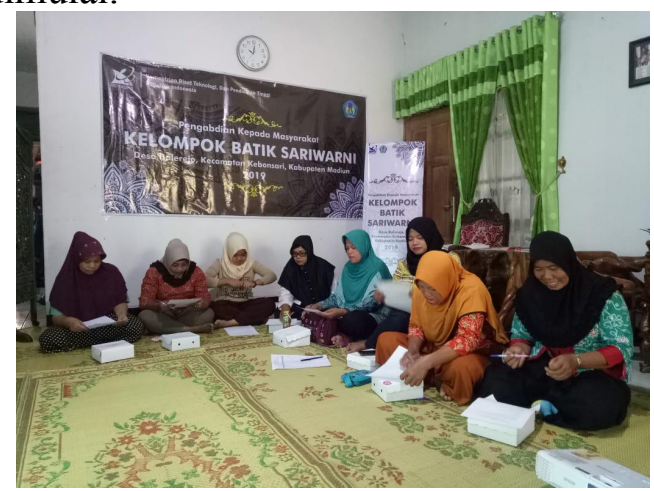

Gambar 3. Suasana saat peserta mengerjakan pretest

Pre test dan post test merupakan tools yang digunakan untuk mengukur peningkatan pengetahuan dari peserta pelatihan setelah dilakukan pemberian materi serta praktek langsung.

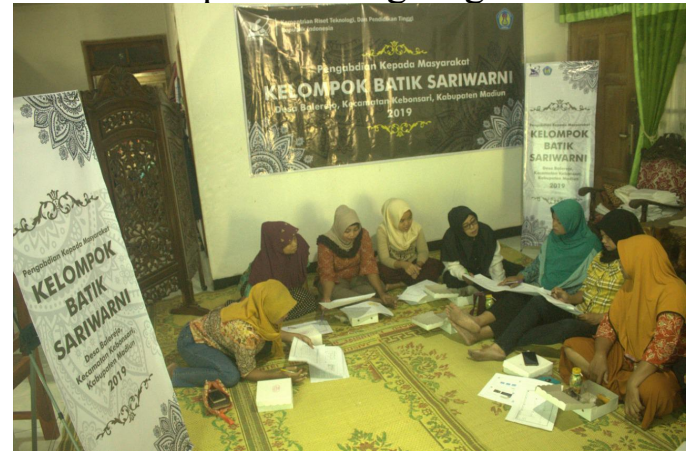

Gambar 4. Peserta Praktek Mengisi Model Kanvas

Pre Test dan post test mempunyai soal yang sama namun diacak urutannya. Berikut adalah hasil dari peningkatan nilai Post Test dari nilai Pre Test.

Tabel 1. Nilai Pre Test dan Post Test

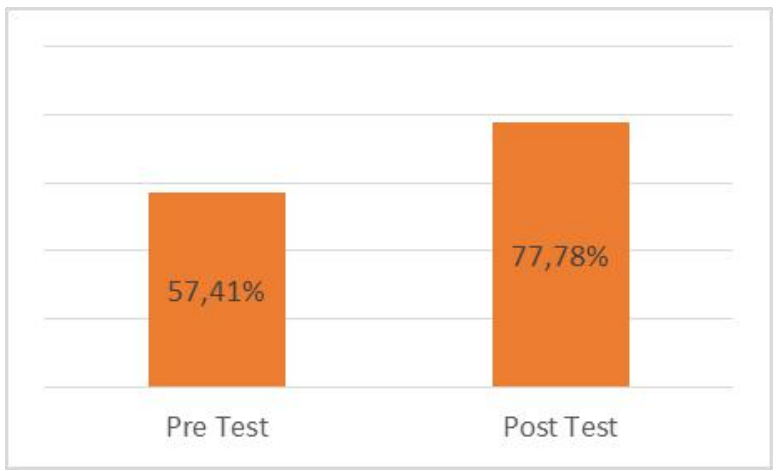

Dari hasil tersebut dapat dilihat bahwa pelatihan yang diberikan dapat meningkatkan pengetahuan peserta sebesar 20,37\%. Dalam proses pelatihan, peserta pun diminta untuk pelakukan praktek langsung dan diskusi pengisian model business canvas batik sariwarni serta penghitungan HPP.

Setelah pelatihan selesai, peserta diminta untuk mengisi tingkat kepuasan untuk melihat tingkat kepuasan peserta terhadap pelihan yang diberikan. Tabel tingkat kepuasan yang digunakan merujuk pada Damayanti (Januar Israhmawan Putra, Damayanti Octavia, 2017). 
Tabel 2. Tingkat Kepuasan Pelatihan Brand dan Pemasaran

\begin{tabular}{|l|l|l|l|}
\hline \multirow{2}{*}{ No } & \multicolumn{2}{|c|}{ Jenis } & \multicolumn{2}{|c|}{ Tingkat Kepuasan } \\
\cline { 3 - 4 } & & Hasil & \multicolumn{1}{|c|}{ Kesimpulan } \\
\hline 1 & Isi Materi Penyuluhan & 4,33 & Baik \\
\hline 2 & Pemberi Materi & 4,33 & Baik \\
\hline 3 & Kesempatan Bertanya & 4,56 & Sangat Baik \\
\hline 4 & $\begin{array}{l}\text { Kejelasan menjawab } \\
\text { pertanyaan }\end{array}$ & 4,67 & Sangat Baik \\
\hline 5 & Manfaat Penyuluhan & 4,67 & Sangat Baik \\
\hline 6 & Waktu Kegiatan & 4,00 & Baik \\
\hline 7 & Waktu Penyuluhan & 4,22 & Baik \\
\hline 8 & Suasana Diskusi & 4,78 & Sangat Baik \\
\hline 9 & Ruang Diskusi & 4,44 & Baik \\
\hline 10 & Kegiatan penyuluhan & 4,67 & Sangat Baik \\
\hline
\end{tabular}

Sumber: Data Primer yang diolah, 2019

Hasil menunjukkan bahwa 50\% pelatihan Baik dan 50\% sisanya Sangat Baik.

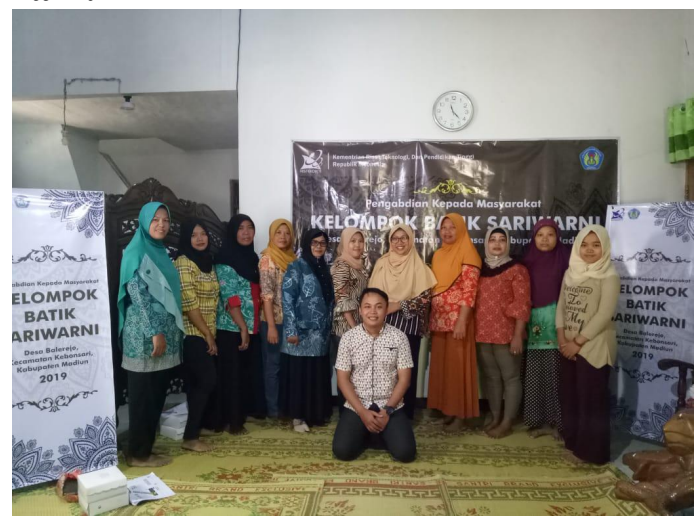

Gambar 5. Suasana Foto Bersama Antara Tim dan Peserta

\section{Pelatihan Digital Marketing}

Pelaihan Digital Marketing diberikan oleh Anggota 3 PKM yaitu Dimas Setiawan S.Kom, M.Kom. Pelatihan ini dihadiri oleh 11 anggota Kelompok Batik Sariwarni. Dari jumlah peserta, terlihat adanya peningkatan dari 9 ke 11 sehingga dapat di nyatakan bahwa peserta pelatihan antusias dan bersemangat.

Teradapat 3 materi dari pelatihan digital marketing yaitu Instagram, Etsy, dan Website. Pelatihan meliputi penjelasan materi, tanya jawab, dan simulasi langsung penggunaan media digital marketing.

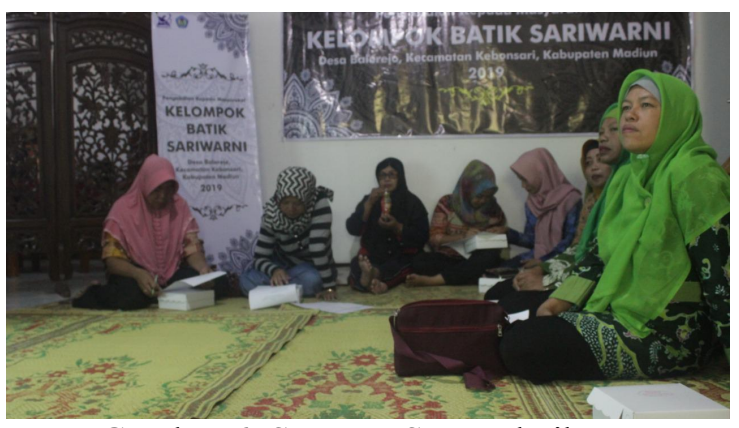

Gambar 6. Suasana Saat Pelatihan

Untuk mengukur tingkat pemahaman peserta terhadap materi yang diberikan, tim melakukan pre test dan post test. Dari kedua test yang dilakukan, terlihat adanya kenaikan sebesar 10,91\%.

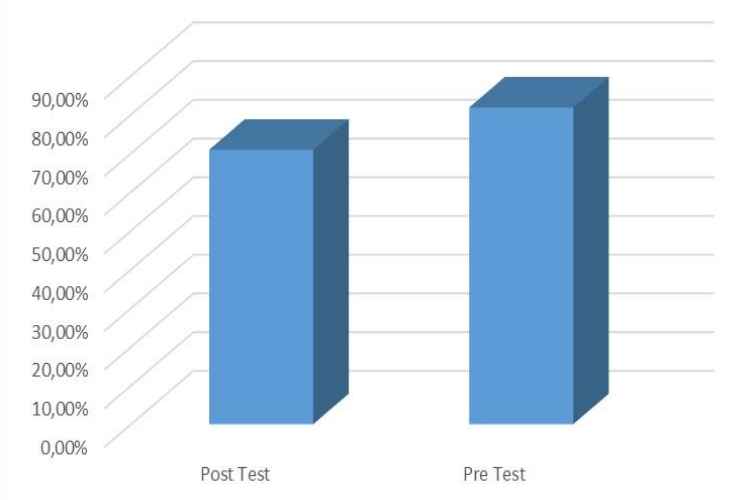

Gambar 7. Hasil Post Test dan Pre Test

Selama pelatihan, peserta di minta untuk praktik langsung mengoperasikan instagram. Hasil yang didapat dalam praktek ini adalah adanya pembaharuan profil dan foto pada IG @ batiktulissariwarni serta adanya unggahan baru setelah 2 tahun tidak pernah mengunggah foto lagi. 

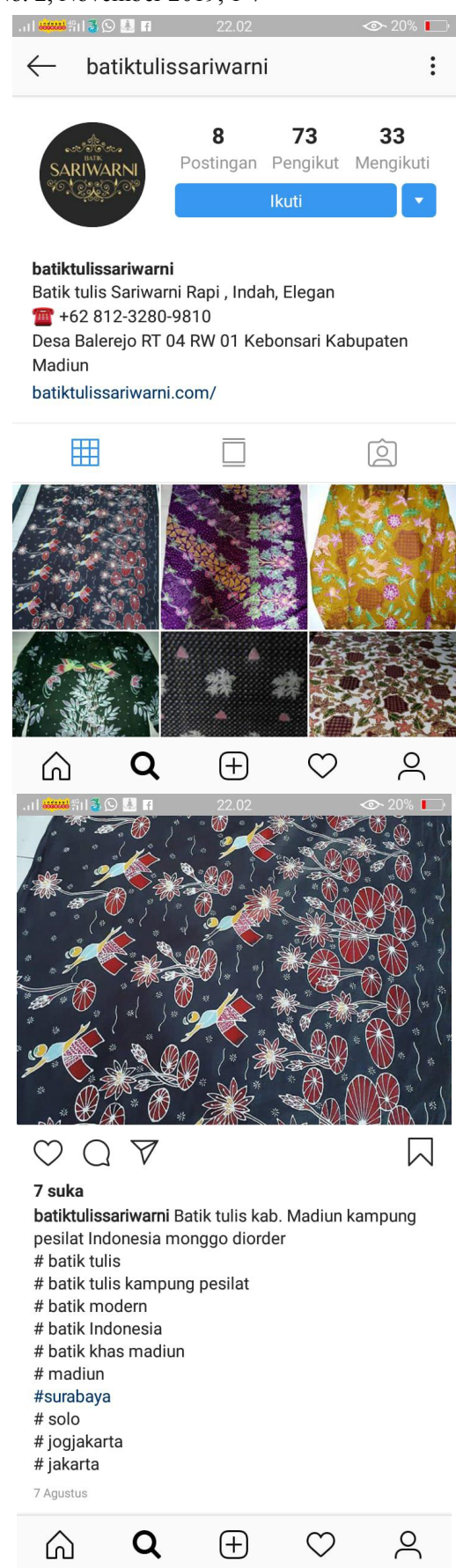

Gambar 8. Instagram saat ini @batiktulissariwarni

Setelah pelatihan selesai, peserta diminta untuk mengisi tingkat kepuasan untuk melihat tingkat kepuasan peserta terhadap pelihan yang diberikan. Tabel tingkat kepuasan yang digunakan merujuk pada Damayanti (2017).
Tabel 3. Tingakat Kepuasan Pelatihan Digital Marketing

\begin{tabular}{|c|c|c|c|}
\hline \multirow{2}{*}{ No } & \multirow{2}{*}{ Jenis } & \multicolumn{2}{|c|}{$\begin{array}{c}\text { Tingkat } \\
\text { Kepuasan }\end{array}$} \\
\hline & & Hasil & $\begin{array}{l}\text { Kesim } \\
\text { pulan }\end{array}$ \\
\hline 1 & Isi Materi Penyuluhan & 4,36 & Baik \\
\hline 2 & Pemberi Materi & 4,27 & Baik \\
\hline 3 & Kesempatan Bertanya & 4,36 & Baik \\
\hline 4 & $\begin{array}{l}\text { Kejelasan menjawab } \\
\text { pertanyaan }\end{array}$ & 4,36 & Baik \\
\hline 5 & Manfaat Penyuluhan & 4,55 & $\begin{array}{l}\text { Sangat } \\
\text { Baik }\end{array}$ \\
\hline 6 & Waktu Kegiatan & 4,27 & Baik \\
\hline 7 & Waktu Penyuluhan & 4,27 & Baik \\
\hline 8 & Suasana Diskusi & 4,09 & Baik \\
\hline 9 & Ruang Diskusi & 4,00 & Baik \\
\hline 10 & Kegiatan penyuluhan & 4,73 & $\begin{array}{l}\text { Sangat } \\
\text { Baik }\end{array}$ \\
\hline
\end{tabular}

Sumber: Data Primer yang diolah, 2019

Tabel diatas menunjukkan tingkat kepuasan "Sangat Baik" sebesar 20\% dan "Baik" sebesar 80\%.

\section{Studi Banding Pemasaran dan IPAL di Kampoeng Batik Laweyan}

Studi banding di kampoeng batik laweyan dilakukan dua kali yaitu untuk mengetahui sistem pembuangan limbah serta pemasaran batik. Pada studi banding IPAL diketuai oleh Nur Ihda Fatikhatin Nisa, S.T., M.T sebagai dosen yang mempunyai kepakaran dalam bidang olah limbah. Di Kampoeng Batik Laweyan tim mendapatkan banyak informasi dan saran terkait pengolahan limbah batik antara lain penggunaan enceng gondok serta pemusatan IPAL. 
Wildanul Isnaini, Dimas Setiawan, Nur Ihda Farikhatin Nisa - Pelatihan Penguatan Brand

Serta Penggunaan Digital Marketing Bagi Kelompok Batik Sariwarni Kabupaten Madiun

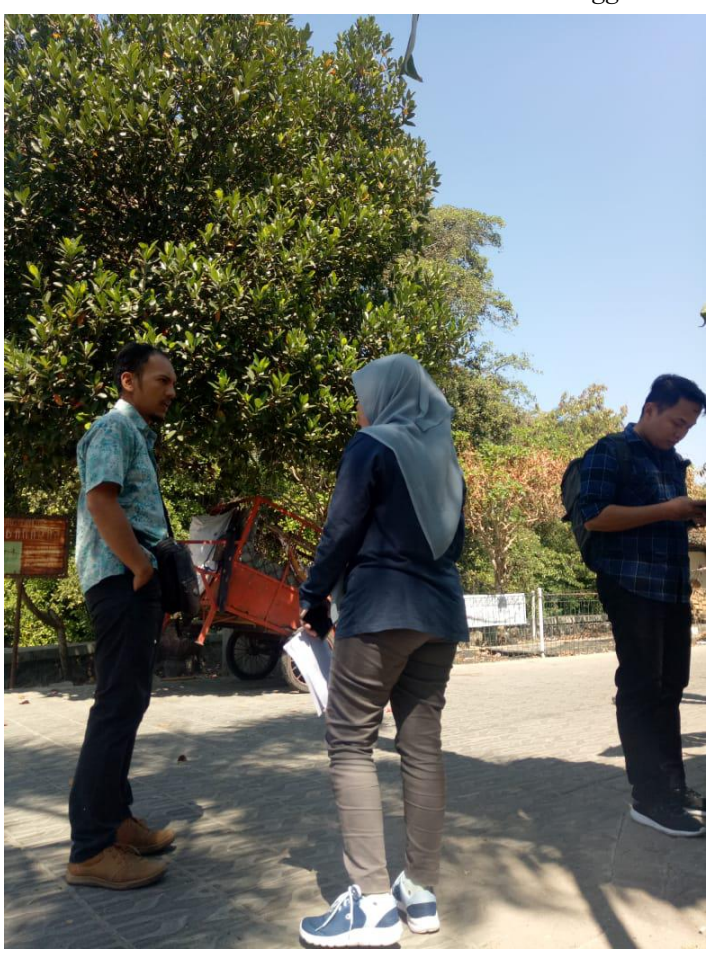

Gambar 9. Suasana Diskusi IPAL

Sedangkan studi banding pemasran batik dilakukan oleh Kelompok Batik Sariwarni terhadap pihak Kampoeng Batik Laweyan. Tujuan dari agenda ini adalah untuk melihat secara langsung dan mencari informasi tentang pengembangan batik dan pemasarannya. Informasi paling penting yang didapat adalah bahwa untuk dapat mengembangkan batik perlu dukungan semua pihak yaitu pemerintah, swasta, universitas, sekolah-sekolah, dan masyarakat itu sendiri.

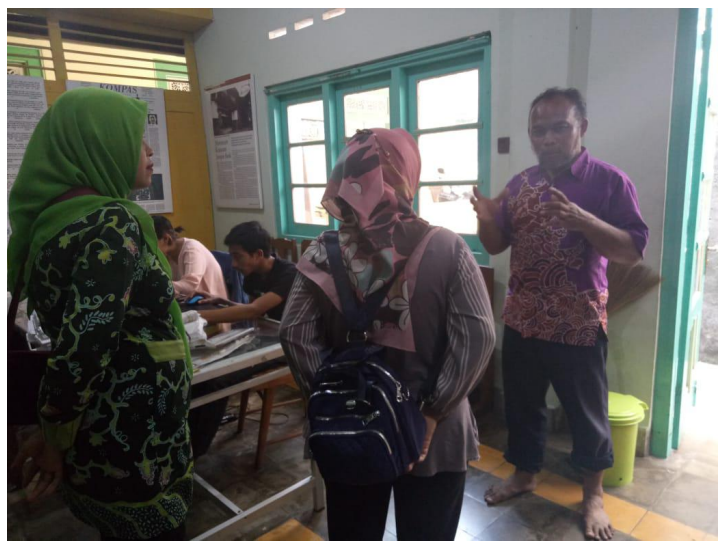

Gambar 10. Suasana Diskusi

\section{SIMPULAN}

Berdasarkan hasil yang telah dicapai sebanyak $70 \%$ dari kegiatan pengabdian masyarakat ini maka dapat disimpulkan:
1. Terdapat 5 program yang telah berjalan yaitu Pelatihan Penguatan Brand dan Pemasaran, Pelatihan Digital Marketing, Studi Banding IPAL di Batik Laweyan, Studi Banding Pemasaran di Batik Laweyan, serta Aksi Nyata Pemasangan Papan dan Penyebaran Brosur

2. Program pelatihan penguatan brand dan pemasaran serta digital marketing berjalan dengan lancar. Pelatihan Penguatan Brand dan Pemasaran dapat meningkatkan pengetahuan sebesar $20,37 \%$ dan pelatihan digital marketing dapat meningkatkan pengetahuan sebesar $10,91 \%$.

3. Antusiasme kelompok batik terhadap program ini baik dibuktikan dengan adanya peningkatan jumlah peserta pada pelatihan hari pertama dan kedua serta adanya peran aktif anggota kelompok terhadap program-program yang telah diberikan.

\section{DAFTAR PUSTAKA}

Jawapos. Batik Sariwarni Jadi Ikon Baleredjo. (diunduh 15 Agustus 2018).

https://www.jawapos.com/entertain ment/travelling/01/08/2016/batiksari-warni-jadi-ikon-baleredjo (akses online: 15 Agustus 2018)

Januar Israhmawan Putra, Damayanti Octavia, S. . (2017). Analisis faktorfaktor yang mempengaruhi kepuasan kon- sumen berbelanja. Jurnal Manajemen Indonesia, 17(2), 103111.

Muljadi. (2009). Efisiensi Instalasi Pengolahan Limbah Cair Industri Batik Cetak dengan Metode FisikaKimia dan Biologi terhadap Penurunan Parameter Pencemar (BOD, COD, dan Logam Berat Krom (Cr). Ekuilibrium, 8(1), 7-16.

Osterwalder, A., Pigneur, Y., Smith, A., \& Movement, T. (2009). Business Model Generation: A Handbook for Visionaries, Game Changers, and 
Jurnal Pengabdian dan Pengembangan Masyarakat,

Vol.2 No. 2, November 2019, 1-7

Challengers. New Jersey: John Wiley \& Sons, Inc.

Satrianti, Prhariezka. 8 Tren Digital Marketing yang Harus Kamu Ketahui. https://id.techinasia.com/8tren-digital-marketing-tahun-2018 (diunduh 16 Agustus 2018) 